\title{
The Inhibitory Activity of Mischarytera lauteriana (F.M.Bailey) Leaf Extracts against a Panel of Bacterial Pathogens
}

\author{
Lindiwe Mpala' ${ }^{1}$, Getmore Chikowe' ${ }^{1}$, Ian Edwin Cock ${ }^{1,2, *}$ \\ 'School of Environment and Science, Griffith University, 170 Kessels Rd, Nathan, Brisbane, Queensland, AUSTRALIA. \\ 2Environmental Futures Research Institute, Griffith University, 170 Kessels Rd, Nathan, Brisbane, Queensland, AUSTRALIA.
}

\begin{abstract}
Introduction: The development of multi-antibiotic resistant strains of bacteria has necessitated the search for new, effective antibacterial therapies. $M$. lauteriana was used by Australian Aborigines as a nutritious food. However, very little research has been published on this species and the antibacterial activity of $M$. lauteriana leaf extracts has not yet been reported. Methods: The ability of $M$. lauteriana leaf extracts to inhibit the growth of gram-negative and gram-positive bacterial species was investigated by disc diffusion and growth time course assays. The growth inhibitory activity was further quantified by MIC determination. Toxicity was determined using the Artemia franciscana nauplii bioassay. Results: The methanolic and aqueous $M$. lauteriana leaf extracts were good inhibitors of the growth of both gram-positive and gram-negative bacteria. The methanolic extract was a particularly good inhibitor of $K$. pneumoniae and $B$. cereus growth, with MIC values of 728 and $515 \mu \mathrm{g} / \mathrm{mL}$ respectively. The aqueous extract was also a good inhibitor of these bacteria (MICs of 953 and $860 \mu \mathrm{g} / \mathrm{mL}$ respectively). Whilst the $M$. lauteriana leaf extracts also inhibited the growth of $P$. mirabilis, S. aureus and $S$. pyogenes, the MIC values (in the range $1000-2000 \mu \mathrm{g} / \mathrm{mL}$ ) were indicative of moderate inhibitory activity. The $M$. lauteriana leaf extracts were further investigated by growth time course assays against $K$. pneumoniae and $B$. cereus. Interestingly, both extracts
\end{abstract}

showed significant growth inhibition within $1 \mathrm{~h}$ of exposure against both bacterial species. All extracts were determined to be nontoxic in the Artemia franciscana nauplii bioassay, indicating their safety for the treatment of gram-positive bacterial infections. Conclusion: The lack of toxicity of the $M$. lauteriana leaf extracts and their growth inhibitory bioactivity against multiple bacteria indicate their potential in the development of new antibiotic chemotherapies.

Key words: Sapindaceae, Corduroy tamarind, Traditional Medicine, Antibacterial, Antibiotic resistant bacteria, Ankylosing spondylitis, Klebsiella pneumoniae, Bacillus cereus.

\section{Correspondence:}

Dr. Ian Edwin Cock

School of Environment and Science and Environmental Futures Research Institute Griffith University, 170 Kessels Rd, Nathan, Brisbane, Queensland, AUSTRALIA.

E-mail: I.Cock@griffith.edu.au

Phone no: : +61-7 37357637

DOI: $10.5530 /$ pc.2019.2.11.

\section{INTRODUCTION}

Despite many significant advances in the treatment of disease, many bacterial pathogens remain difficult to treat effectively as many strains have become either extremely (XDR) or totally drug resistant (TDR) to common clinically used antibiotics. ${ }^{1}$ There are now limited therapeutic options for the diseases caused by these pathogens and the problem is expected to worsen in the future as bacteria exchange resistance genes and more strains become multi-drug resistant (MDR). The development of alternative antibacterial treatment modalities has become crucial and is considered by the World Health Organisation (WHO) to be one of the most serious challenges facing medical science. ${ }^{2}$ For a number of reasons reviewed elsewhere, ${ }^{1}$ it is unlikely that the previous methods of antibiotic discovery/development will be as successful in the future and new treatment modalities are urgently required.

Plants produce a wide variety of secondary compounds, which provide them characteristic pigment, odour and flavour characteristics and may also give them antimicrobial properties. ${ }^{3}$ Traditional plant derived medicines have been used in most parts of the world for a variety of therapeutic purposes, including fighting microbial disease. Indeed, the ability of plant extracts to block the growth of pathogenic bacteria has become the focus of much recent study. ${ }^{4,5}$ Much of the research into traditional medicinal plant use has focused on Asian, ${ }^{6,7}$ African ${ }^{8-12}$ and South American ${ }^{13,14}$ plants. However, the therapeutic potential of the flora of Australia has also received recent attention. The first Australians had well-developed medicinal systems and understood the therapeutic properties of a wide variety of Australian plants and how to use them effectively. ${ }^{15}$ Whilst studies have reported antibacterial activity for some Australian plant species, ${ }^{16-19}$ the antibacterial activity of many Australian native plants remains unexamined. Mischarytera lauteriana (F.M.Bailey) (Family Sapindaceae; synonyms Nephelium lauteriana (F.M.Bailey), Arytera lauteriana (F.M.Bailey); common name corduroy tamarind) is a species of rainforest tree that is endemic to the north eastern regions of Australia. It is a medium sized, sparsely branched understory tree which has wavy elongated leaves (Figure 1a). Small white-yellow flowers form as inflorescences (Figure 1b). These flowers develop into fruit capsules containing bright orange fruit (Figure 1c). M. lauteriana fruit were used as a nutritious food source by Australian Aborigines. Surprisingly, we were unable to find any studies examining either the therapeutic properties, nutritional value or the phytochemistry of this species. This study was undertaken to screen of $M$. lauteriana leaf extracts for the ability to inhibit the growth of a panel of gram-positive and gram-negative bacterial pathogens.

\section{MATERIALS AND METHODS}

\section{Plant Collection and Extraction}

Mischarytera lauteriana (F.M.Bailey) leaves were obtained from Philip Cameron, senior botanical officer, Mt Cootha Botanical Gardens, Brisbane, Australia. The leaf samples were dried in a Sunbeam food dehydrator and stored at $-30^{\circ} \mathrm{C}$. Prior to use, the dried leaves were freshly ground to a coarse powder and $1 \mathrm{~g}$ quantities were weighed into separate tubes. A volume of $50 \mathrm{~mL}$ of AR grade methanol (Ajax Fine Chemicals, Australia) or sterile deionised water was added to individual $1 \mathrm{~g}$ masses of the plant material and extracted for $24 \mathrm{hrs}$ at $4^{\circ} \mathrm{C}$ with gentle shaking. The extract was filtered through filter paper (Whatman No. 54) under vacuum, followed by lyophilisation. The resultant pellets were weighed 


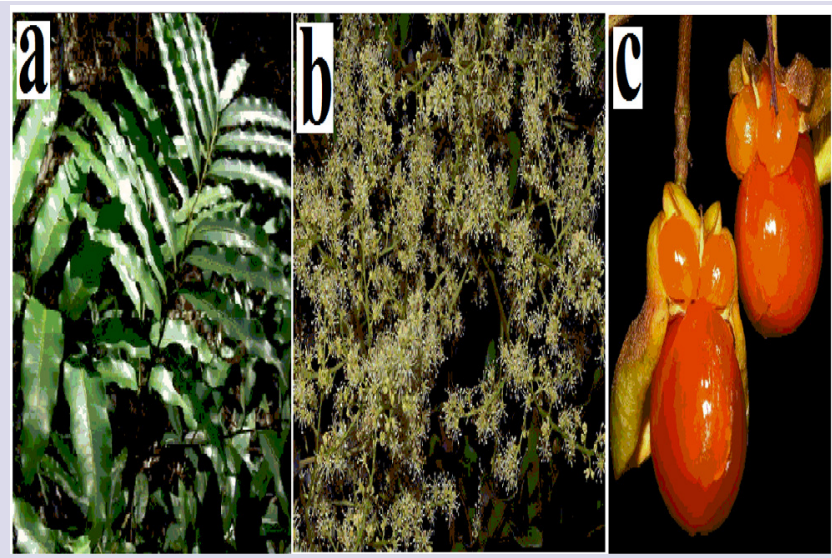

Figure 1: M. lauteriana (a) leaves, (b) flowers and (c) fruit.

Briefly, the $M$. lauteriana leaf extracts were diluted in deionised water ( $1 \%$ DMSO) and tested across a range of concentrations. Discs were individually infused with $10 \mu \mathrm{L}$ of each extract, allowed to dry and placed onto the inoculated plates. The assay was completed as outlined above and graphs of the ZOI versus ln concentration were plotted for each extract. Linear regression was used to determine the MIC values of each extract.

\section{Bacterial Growth Time Course Assay}

Bacterial growth time course studies were performed as previously described. ${ }^{26}$ Briefly, $3 \mathrm{~mL}$ of the gram-positive bacterial species in nutrient broth were individually added to $27 \mathrm{~mL}$ nutrient broth containing $3 \mathrm{~mL}$ of $10 \mathrm{mg} / \mathrm{mL}$ of the extract to give a final extract concentration of $1000 \mu \mathrm{g} /$ $\mathrm{mL}$ in the assay. The tubes were incubated at $37^{\circ} \mathrm{C}$ with gentle shaking. The optical density was measured hourly at $550 \mathrm{~nm}$ for a $6 \mathrm{~h}$ incubation period. Control tubes were incubated under the same conditions but without the extract. All assays were performed three times in triplicate $(n=9)$.

\section{Toxicity Screening}

to determine the extraction yield and subsequently dissolved in $10 \mathrm{~mL}$ sterile deionised water (Containing 1\% DMSO). The extracts were passed through $0.22 \mu \mathrm{m}$ filter (Sarstedt) and stored at $4^{\circ} \mathrm{C}$ until use.

\section{Qualitative Phytochemical Studies}

Phytochemical analysis of the $M$. lauteriana leaf extracts for the presence of saponins, phenolic compounds, flavonoids, phytosteroids, triterpenoids, cardiac glycosides, anthraquinones, tannins and alkaloids was conducted by standard assays. ${ }^{16,17}$

\section{Antibacterial Screening}

\section{Test Microorganisms}

All media was purchased from Oxoid Ltd., Australia. The reference strains of E. coli (ATCC157293), Klebsiella pneumoniae (ATCC31488), Proteus mirabilis (ATCC21721) and Streptococcus pyogenes (ATCC19615) were purchased from American Tissue Culture Collection (ATCC), USA. Clinical isolate microbial strains of Bacillus cereus and Staphylococcus aureus were obtained from Ms Michelle Mendell and Ms Jane Gifkins, Griffith University. All stock cultures were subcultured and maintained in nutrient broth at $4^{\circ} \mathrm{C}$.

\section{Evaluation of Antimicrobial Activity}

Antimicrobial activity of the M. lauteriana leaf extracts was determined using a modified disc diffusion assay. ${ }^{20-23}$ Briefly, $100 \mu \mathrm{L}$ of the each bacterial suspension in log phase was spread onto individual nutrient agar plates and the extracts were tested for antibacterial activity using $6 \mathrm{~mm}$ sterilised filter paper discs. The discs were each infused with $10 \mu \mathrm{L}$ of the individual plant extract, allowed to dry and placed onto the inoculated plates. The plates were allowed to stand at $4^{\circ} \mathrm{C}$ for $2 \mathrm{~h}$ before incubation at $37^{\circ} \mathrm{C}$ for $24 \mathrm{~h}$. The diameters of the zones of inhibition (ZOIs) were measured to the closest whole millimetre. Each assay was performed three times in triplicate $(n=9)$. Mean values $( \pm$ SEM) are reported in this study. Standard discs of ampicillin $(10 \mu \mathrm{g})$ and chloramphenicol $(10 \mu \mathrm{g})$ were obtained from Oxoid, Australia and were used as positive controls to compare antibacterial activity. Filter discs infused with $10 \mu \mathrm{L}$ of distilled water were used as a negative control.

\section{Minimum Inhibitory Concentration (MIC) Determination}

The minimum inhibitory concentration (MIC) of each extract against susceptible bacteria was determined as previously described. ${ }^{24,25}$

\section{Artemia franciscana Nauplii Toxicity Screening}

Toxicity was tested using an adapted Artemia franciscana nauplii lethality assay. ${ }^{27-29}$ Briefly, A. franciscana nauplii were incubated in the presence of the extracts, reference toxin $(1 \mathrm{mg} / \mathrm{mL}$ potassium dichromate) or artificial seawater (Negative control) at $25 \pm 1^{\circ} \mathrm{C}$ under artificial light. All treatments were performed three times in triplicate $(n=9)$. The number of dead were counted in each well at $24 \mathrm{~h}$ and $48 \mathrm{~h}$. At the completion of the $48 \mathrm{~h}$ exposure period, the remaining live nauplii were sacrificed and the total number of nauplii in each well were counted and used to calculate the $\%$ mortality per well. LC $_{50}$ values were calculated for each treatment using probit analysis.

\section{Statistical Analysis}

Data are expressed as the mean \pm SEM of three independent experiments with internal triplicates $(n=9)$. One-way ANOVA was used to calculate statistical significance between control and treated groups, with a $P$ value $<0.01$ considered to be statistically significant.

\section{RESULTS}

\section{Liquid Extraction Yields and Qualitative Phytochemical Screening}

Extraction of $1 \mathrm{~g}$ of dried and powdered M. lauteriana leaves with methanol and water yielded 256 and $184 \mathrm{mg}$ of extracted material respectively (Table 1). The extracts were resuspended in $10 \mathrm{~mL}$ of deionised water (Containing 1\% DMSO), resulting in an extract concentration shown in Table 1. Qualitative phytochemical studies showed that both extracts had similar phytochemical profiles. Both contained high levels of phenolic compounds as well as moderate levels of flavonoids, triterpenoids and saponins. Lower levels of tannins were also detected. Cardiac glycosides, phytosterols, alkaloids and anthraquinones were completely absent or below the detection thresholds for these assays.

\section{Antimicrobial Activity}

To determine the growth inhibitory activity of the $M$. lauteriana leaf extracts, aliquots $(10 \mu \mathrm{L})$ of each extract were screened in the disc diffusion assay. The $M$. lauteriana leaf extracts were effective at inhibiting the growth of 2 of the 3 gram-negative bacterial species tested (Figure 2). For both of these bacteria, the methanolic extract was a substantially more potent inhibitor of bacterial growth than the aqueous extract was. 
Table 1: The Mass of Dried Extracted Material, the Concentration after Resuspension in Deionised Water and Qualitative Phytochemical Screenings of the M. lauteriana Leaf Extracts.

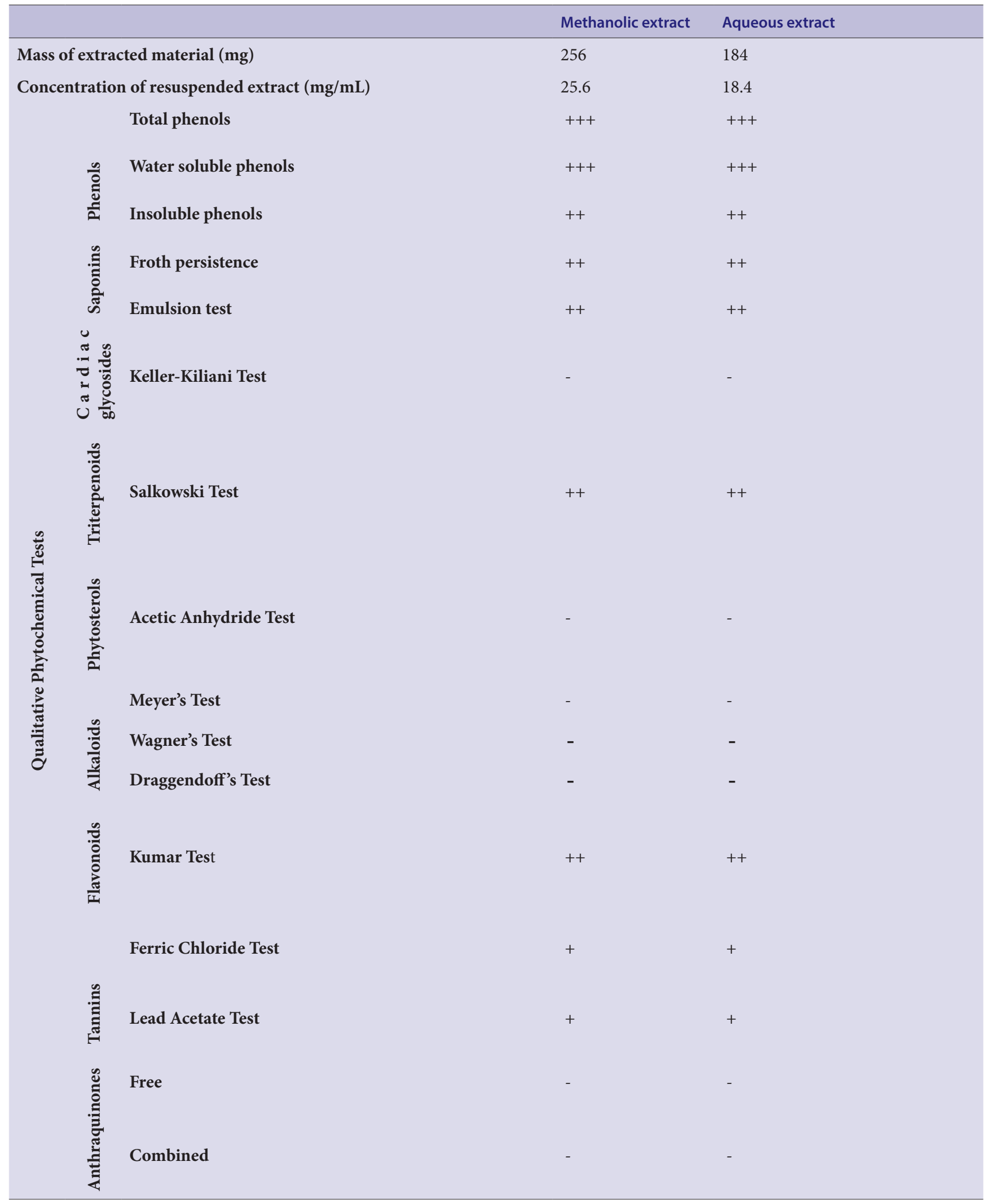

+++ indicates a large response; ++ indicates a moderate response; + indicates a minor response; - indicates no response in the assay. 
Only E. coli was completely resistant to the M. lauteriana leaf extracts. In contrast, $K$. pneumoniae was highly susceptible to the methanolic leaf extract, with a ZOI of $9.6 \mathrm{~mm}$ measured. Both positive control antibiotics (ampicillin and chloramphenicol) were potent growth inhibitors, with ZOI's of up to $14.7 \mathrm{~mm}$ (chloramphenicol against E. coli).

The gram-positive bacterial species appeared more susceptible to the extracts than the gram-negative species. Indeed, the growth of all gram-positive bacteria was inhibited by the M. lauteriana leaf extracts (Figure 3). As noted for the gram-negative bacteria, the methanolic extract was a substantially better inhibitor of gram-positive bacterial growth. B. cereus was most susceptible to the inhibitory effects of the extracts, with ZOIs of nearly $11 \mathrm{~mm}$ measured (Figure 3 ). Indeed, the methanolic extract produced ZOIs that were only slightly smaller than the chloramphenicol control. This is noteworthy as the controls were tested at relatively high doses $(10 \mu \mathrm{g} / \mathrm{disc})$. Furthermore, the control antibiotics are pure compounds, whereas the extracts are crude mixtures and the active compound(s) would be expected to be a minor $\%$ of the overall extracts mass. Therefore, these extracts may be particularly promising as targets for antibiotic drug discovery. The methanolic M. lauteriana leaf extract was also an effective inhibitors of $S$. pyogenes growth (Figure $3)$, albeit with a smaller ZOI ( 8mm) noted. The ZOI measured against this bacterium was comparable to that of the chloramphenicol control, demonstrating its potential for the development of novel antibacterial chemotherapeutics. As $S$. pyogenes can cause a wide variety of diseases including pharyngitis, impetigo and rheumatic fever depending on the tissue that it infects, these extracts may be particularly useful as targets for antibiotic discovery. Only the methanolic M. lauteriana leaf extract inhibited the growth of $S$. aureus, whilst the aqueous extract was completely ineffective. Smaller ZOIs $(7.3 \mathrm{~mm})$ were recorded against this bacterium, indicating only low to moderate activity.

The antimicrobial efficacy was further quantified by determining the MIC value. The methanolic and aqueous extracts were particularly good inhibitors of K. pneumoniae (MICs of 728 and $953 \mu \mathrm{g} / \mathrm{mL}$ for the methanolic and aqueous extracts respectively) and B. cereus growth (MICs of 515 and $860 \mu \mathrm{g} / \mathrm{mL}$ for the methanolic and aqueous extracts respectively). Both extracts were also moderate inhibitors of $P$. mirabilis growth (MIC values of 1126 and $2030 \mu \mathrm{g} / \mathrm{mL}$ respectively), whilst the methanolic extract was also a moderate inhibitor of $S$. aureus growth $(\mathrm{MIC}=1388 \mu \mathrm{g} / \mathrm{mL})$. E. coli was completely resistant to the methanolic and aqueous $M$. lauteriana leaf extracts at all concentrations tested.

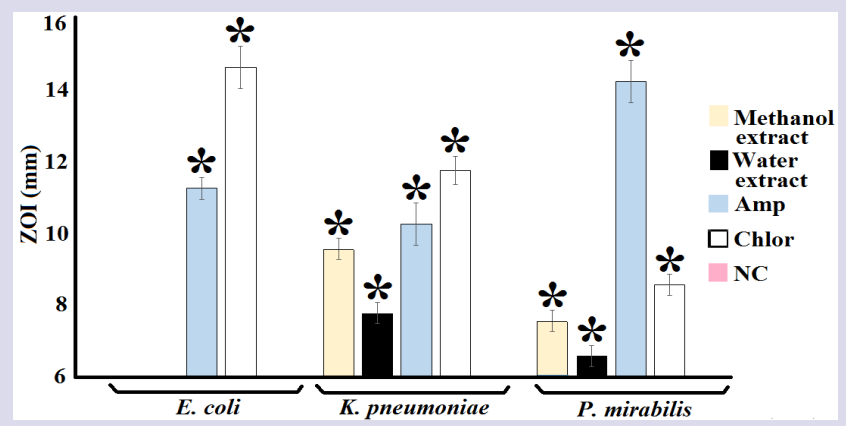

Figure 2: Growth Inhibitory activity of the M. lauteriana leaf extracts and reference antibiotics against gram-negative bacterial species measured as ZOls ( $\mathrm{mm}) \pm \mathrm{SEM}$. Ampicillin (Amp) and chloramphenicol (Chlor) standard discs $(10 \mu \mathrm{g})$ were used as positive controls. All assays were completed three times, each with internal triplicates $(n=9)$ and the results are expressed as mean zones of inhibition $(\mathrm{mm}) \pm$ SEM. * indicates results that are significantly different to the untreated control $P<0.01)$.

\section{Bacterial Growth Time Course Assay}

The antibacterial activity of the $M$. lauteriana leaf methanolic and aqueous extracts was further investigated against $K$. pneumonia and $B$. cereus by bacterial growth time course assays in the presence and absence of the extracts (Figure 4). The starting concentration of the extract used in these assays was $1000 \mu \mathrm{g} / \mathrm{mL}$. The M. lauteriana leaf methanolic and aqueous leaf extracts both significantly inhibited K. pneumoniae within $1 \mathrm{~h}$ of exposure, indicating a rapid antimicrobial action (Figure $4 \mathrm{a})$. The absorbance of the K. pneumonia culture remained substantially lower than the untreated control for the first $4 \mathrm{hrs}$ of exposure. After that time, the absorbance increased to approximately the same level as the control, indicating that the methanolic and aqueous extracts are bacteriostatic rather than bacteriocidal at the concentrations tested.

A different trend was noted for the $M$. lauteriana leaf methanolic extracts against when tested against $B$. cereus growth (Figure $4 \mathrm{~b}$ ). The absorbance of the $B$. cereus culture (and thus the bacterial growth) remained substantially lower than the untreated control for the entire $6 \mathrm{~h}$ incubation period, indicating that the methanolic extract may be bacteriocidal at the concentrations tested (Figure $4 \mathrm{~b}$ ). The aqueous extract was also rapid in its inhibition of $B$. cereus growth, with a significant decrease in bac-

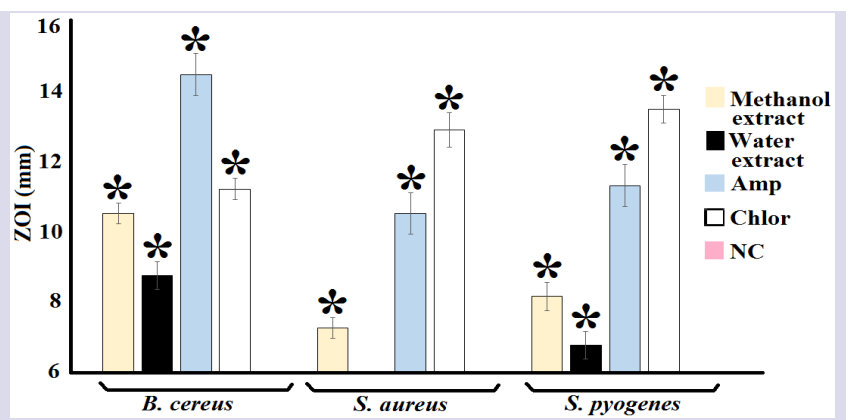

Figure 3: Growth inhibitory activity of the $M$. lauteriana leaf extracts and reference antibiotics against gram-positive bacterial species measured as ZOls (mm) \pm SEM. Ampicillin (Amp) and chloramphenicol (Chl) standard discs $(10 \mu \mathrm{g})$ were used as positive controls. NC = negative control. All assays were completed three times, each with internal triplicates $(n=9)$ and the results are expressed as mean zones of inhibition $(\mathrm{mm}) \pm \mathrm{SEM} .{ }^{*}$ indicates results that are significantly different to the untreated control $P<0.01$ ).

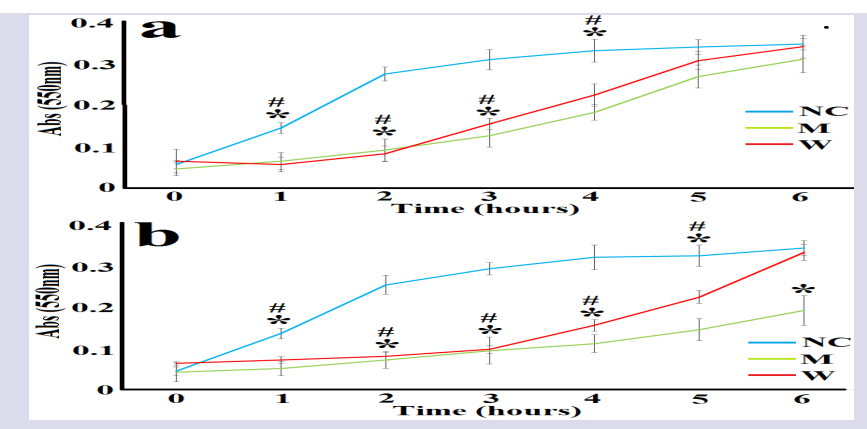

Figure 4: Bacterial growth curves the M. lauteriana leaf extracts against (a) K. pneumonia and (b) B. cereus. All bioassays were performed three times in triplicate $(n=9)$ and are expressed as mean \pm SEM. ${ }^{*}=$ methanolic extract results that are significantly different between the treated and the untreated control growth; \# = aqueous extract results that are significantly different between the treated and the untreated control growth $(P<0.01)$. 
terial growth also noted within the first hour of incubation. However, in contrast to the inhibition of $B$. cereus growth by the methanolic extract, $B$. cereus growth had returned to similar levels to that of the untreated control by the end of the $6 \mathrm{~h}$ incubation period (as judged by turbidity). This may indicate that the aqueous $M$. lauteriana leaf extracts had bacteriostatic effects at the tested concentration, rather than bactericidal effects.

\section{Quantification of Toxicity}

The toxicity of the M. lauteriana leaf extracts was initially tested at $2 \mathrm{mg} /$ $\mathrm{mL}$ in the A. franciscana nauplii bioassay (Figure 5). The mortality in the presence of both extracts was not significantly different to that of the untreated control at $24 \mathrm{~h}$ and thus they were deemed to be non-toxic. Extracts with $24 \mathrm{~h} \mathrm{LC}_{50}$ values $>1000 \mu \mathrm{g} / \mathrm{mL}$ have previously been defined as non-toxic. ${ }^{28,29}$ In contrast, the potassium dichromate positive control induced substantial mortality within 4 h (Results not shown), with $100 \%$ mortality induction seen by $24 \mathrm{~h}$. The mortality induction remained low for the M. lauteriana leaf extracts at $48 \mathrm{~h}$. Indeed, the $\%$ mortality induction was substantially $<50 \%$ for all extracts at all times tested and therefore it was not possible to determine $\mathrm{LC}_{50}$ values for any of the $M$. lauteriana leaf extracts (Table 2).

\section{DISCUSSION}

Despite the initial potency of many antibiotic chemotherapies, recent increases in bacterial resistance to many antibiotics has made the development of new antibiotic therapies a high priority. ${ }^{1} \mathrm{~A}$ parallel decrease in the introduction of new antibiotic therapies in recent years has further compounded this problem. As a result, interest in re-evaluating medicinal plants for new antibiotic chemotherapies has escalated substantially. ${ }^{30}$ Interestingly, we were unable to find records of the medicinal usage of $M$. lauteriana by Australian Aborigines. Furthermore, no scientific evaluations have yet evaluated any therapeutic properties of this species. To the best of our knowledge, this is the first study to report bacterial growth inhibitory activity for this species.

The ability of the M. lauteriana leaf extracts to inhibit the growth of both gram-positive and gram-negative bacteria is in agreement with previous reports of the antibacterial activity of other Australian plant species. ${ }^{31,32}$ However, a slightly greater susceptibility of the gram-positive bacteria was noted compared to the gram-negative species. The greater

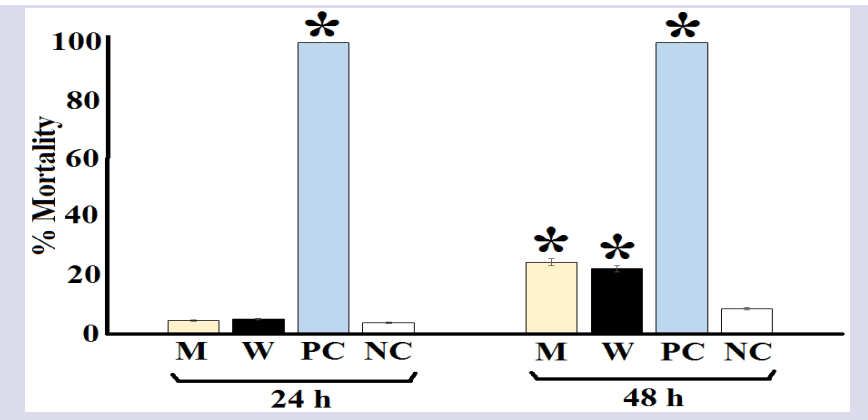

Figure 5: The lethality of the $M$. lauteriana leaf extracts $(2000 \mu \mathrm{g} / \mathrm{mL})$, potassium dichromate control $(1000 \mu \mathrm{g} / \mathrm{mL}$ ) and seawater (negative control). All bioassays were performed three times in triplicate $(n=9)$ and are expressed as mean \pm SEM. ${ }^{*}$ indicates results that are significantly different to the untreated (seawater) control at the equivalent exposure time $(P<0.01)$." susceptibility of gram-positive bacteria to the M. lauteriana leaf extracts noted in this study is in agreement with previously reported results for South American, ${ }^{13,33}$ African ${ }^{34,35}$ and Australian ${ }^{36}$ plant extracts. Results within our laboratory have also confirmed the greater susceptibility of gram-positive bacteria towards other Australian plant extracts. ${ }^{37,38}$ The gram-negative bacterial cell wall outer membrane is thought to act as a barrier to many substances including antibiotics. ${ }^{39}$ The uptake of the $M$. lauteriana leaf extract antibiotic compounds by gram-negative bacteria is presumably affected by the cell wall outer membrane. In contrast, other studies have demonstrated that gram-negative bacteria are often more susceptible to plant extracts from different Australian plant species. ${ }^{40-42}$ Whilst an investigation of the phytochemistry of the M. lauteriana leaf extracts was beyond the scope of our study, moderate to high levels of polyphenolics, flavonoids, triterpenoids and saponins were noted in the extracts in the qualitative phytochemical screening study. Lower levels of tannins were also detected. Flavonoids have well established bacterial growth inhibitory activities. ${ }^{43}$ The flavonoids kaempferol and myricetin have been reported to be potent growth inhibitors of a panel of bacterial pathogens. ${ }^{44}$ Similarly, quercetin, rutin and their corresponding glycosides inhibit the growth of Pseudomonas maltophilia and Enterobacter cloacae. ${ }^{45}$ The antimicrobial activity of terpenoids has also been extensively documented. Monoterpenoids including $\alpha$-pinene, $\beta$-pinene, sabinene, mycrene, terpinene, limonene, piperitone and $\beta$-phellandrene inhibit the growth of a panel of bacteria, including several antibiotic resistant strains of Enterobacteriaceae. ${ }^{43}$ The antibacterial activities for several sesquiterpenoids including $\alpha$-cubebene, copaene and caryophyllene have been reported. ${ }^{43}$ Similarly, many tannin compounds have bacterial growth inhibitory activity. Gallotannins inhibit the growth of a broad spectrum of bacterial species ${ }^{46}$ through a variety of mechanisms including binding cell surface molecules including lipotoichoic acid and proline-rich cell

Table 2: Minimum Inhibitory Concentrations $(\mu \mathrm{g} / \mathrm{mL})$ of the $M$. lauteriana leaf Extracts Against each Bacterial Strain and $\mathrm{LC}_{50}$ values $(\mu \mathrm{g} / \mathrm{mL})$ against Artemia nauplii.

\begin{tabular}{lccc}
\hline & \multicolumn{2}{c}{ MIC or $\mathrm{LC}_{50}(\mu \mathrm{g} / \mathrm{mL})$} \\
Organism & Exposure time (h) & $\begin{array}{c}\text { Methanolic } \\
\text { extract }\end{array}$ & Aqueous extract \\
\hline E. coli & 24 & - & - \\
K. pneumoniae & 24 & 728 & 953 \\
$\begin{array}{l}\text { P. mirabilis } \\
\text { B. cereus }\end{array}$ & 24 & 1126 & 2030 \\
$\begin{array}{l}\text { S. aureus } \\
\text { S. pyogenes }\end{array}$ & 24 & 515 & 860 \\
Artemia & 24 & 1388 & - \\
nauplii & 24 & 1050 & 1692 \\
\hline
\end{tabular}

Numbers indicate the mean MIC or $\mathrm{LC}_{50}$ values of three independent experiments in triplicate $(n=9)$. - indicates that an the extract did not inhibit bacterial growth at any concentration tersted; CND indicates that an $\mathrm{LC}_{50}$ could not be determined as the mortality did not exceed $50 \%$ at any concentration tested. 
surface proteins, ${ }^{47,48}$ and by inhibiting glucosyltransferase enzymes. ${ }^{49}$ Elligitannins are also highly potent inhibitors of bacterial growth, with MIC values as low as $62.5 \mu \mathrm{g} / \mathrm{mL} .{ }^{46,48}$ Ellagitannins have also been reported to function via several antibiotic mechanisms including interaction with cytoplasmic oxidoreductases and by disrupting bacterial cell walls. ${ }^{46,48}$ Thus, it is likely that multiple compounds within the M. lauteriana leaf extracts are contributing to the antibacterial activity reported here.

The findings reported here also indicate that the extracts examined were non-toxic $\left(\mathrm{LC}_{50}>1000 \mu \mathrm{g} / \mathrm{mL}\right.$ ) in the Artemia nauplii bioassay. Whilst toxicity was assessed in this study with the test organism A. franciscana, toxicity towards $A$. franciscana has previously been shown to correlate well with toxicity towards human cells for many toxins. ${ }^{28,29}$ However, further studies are required to determine whether this is also true for the $M$. lauteriana leaf extracts examined in these studies. The results of this study indicate that the M. lauteriana leaf extracts may be good candidates for antimicrobial drug discovery and further examination is warranted. Whilst the extracts examined in this report have potential as bacterial growth inhibitors, caution is needed before these compounds can be applied to medicinal purposes. Purification and identification of the bioactive components is needed to examine the mechanisms of action of these agents.

\section{CONCLUSION}

The growth inhibitory activity of the M. lauteriana leaf extracts against gram-positive and gram-negative bacteria and their lack of toxicity indicate their potential for the development of novel chemotherapies to treat a variety of diseases caused by bacterial pathogens. Further studies aimed at the purification of the bioactive components are needed to examine the mechanisms of action of these agents.

\section{ACKNOWLEDGEMENT}

The authors are grateful to Michelle Mendell and Jane Gifkins of Griffith University for providing the clinical bacterial strains used in this study. Financial support for this work was provided by the Environmental Futures Research Institute and the School of Natural Sciences, Griffith University, Australia.

\section{CONFLICT OF INTEREST}

The authors declare no conflicts of interest.

\section{ABBREVIATIONS}

DMSO: Dimethyl sulfoxide; $\mathbf{L C}_{50}$ : The concentration required to achieve $50 \%$ mortality; MIC: Minimum inhibitory concentration; ZOI: Zone of inhibition.

\section{REFERENCES}

1. Cheesman MJ, Ilanko A, Blonk B, Cock IE. Developing new antimicrobial therapies: Are synergistic combinations of plant extracts/compounds with conventional antibiotics the solution?. Pharmacognosy Reviews. 2017;11(22):57-72. DOI: 10.4103/phrev.phrev_21_17

2. WHO. Antimicrobial Resistance. World Health Organization. 2016. Available from: http://www.who.int/mediacentre/factsheets/fs194/en/. [Cited on 2017 May 10].

3. Cowan MM. Plant products as antibacterial agents. Clinical Microbiology Reviews. 1999;12(4):564-82.

4. Bhavnani SM, Ballow $\mathrm{CH}$. New agents for Gram-positive bacteria. Current Opinion in Microbiology. 2000;3(5):528-34

5. Chiariandy $\mathrm{CM}$, Seaforth $\mathrm{CE}$, Phelps $\mathrm{RH}$, et al. Screening of medicinal plants from Trinidad and Tobago for antimicrobial and insecticidal properties. Journal of Ethnopharmacology. 1999;64(3):265-70.

6. Hart C, Cock IE. An examination of the antimicrobial and anticancer properties of Garcinia cambogia fruit pericarp extracts. BEMS Reports. 2016;2(2):23-6. DOI: $10.5530 / B E M S .2016 .1 .5$
7. Wright MH, Arnold MSJ, Lee CJ, et al. Qualitative phytochemical analysis and antibacterial activity evaluation of Indian Terminalia spp. against the pharyngitis causing pathogen Streptococcus pyogenes. Pharmacognosy Communications. 2016;6(2):85-92. DOI: 10.5530/pc.2016.2.6

8. Hübsch Z, Zyl RLV, Cock IE, et al. Interactive antimicrobial and toxicity profiles of conventional antimicrobials with Southern African medicinal plants. South African Journal of Botany. 2014;93:185-97. DOI: 10.1016/j.sajb.2014.04.005

9. Arkhipov A Sirdaarta J, Rayan $P$ et al. An examination of the antibacterial, antifungal, anti-Giardial and anticancer properties of Kigelia africana fruit extracts. Pharmacognosy Communications. 2014;4(3):62-76. DOI: 10.5530/ pc.2014.3.7

10. Rabadeaux C, Vallette L, Sirdaarta J, et al. An examination of the antimicrobial and anticancer properties of Khaya senegalensis (Desr.) A. Juss. bark extracts. Pharmacognosy Journal. 2017;9(2):175-84. DOI: 10.5530/pj.2017.4.82

11. Cock IE, Vuuren SFV. Anti-Proteus activity of some South African medicinal plants: Their potential for the treatment and prevention of rheumatoid arthritis. Inflammopharmacology. 2014;22(1):23-36. DOI 10.1007/s10787-013-0179-3

12. Cock IE, Van VSF. The potential of selected some South African plants with antiKlebsiella activity for the treatment and prevention of ankylosing spondylitis Inflammopharmacology. 2015;23(1):21-35. DOI: 10.1007/s-10787-013-0179-3

13. Mohanty S, Cock IE. Evaluation of the antibacterial activity and toxicity of Myrciaria caulifloria methanolic leaf and fruit extracts. Internet Journal of Microbiology. 2009;7:2

14. Paz EA, Cerdeiras MP, Fernandez J, et al. Screening of Uruguayan medicinal plants for antimicrobial activity. Journal of Ethnopharmacology. 1995;45(1):6770.

15. Cock IE. Medicinal and aromatic plants - Australia. In Ethnopharmacology, Encyclopedia of Life Support Systems (EOLSS). Developed under the auspices of UNESCO. Oxford, UK: EOLSS Publishers; 2011. Available from: http://www. eolss.net.

16. Sirdaarta J, Matthews B, Cock IE. Inhibitory activity of Kakadu plum fruit extracts against microbial triggers of rheumatoid arthritis: Identification of stilbene and tannin components. Journal of Functional Foods. 2015;17(1):610-20.

17. Winnett $V$, Sirdaarta $J$, White $A$, et al. Inhibition of Klebsiella pneumonia growth by selected Australian plants: natural approaches for the prevention and management of ankylosing spondylitis. Inflammopharmacology. 2017;25(2):223-35. DOI: 10.1007/s10787-017-0328-1

18. Wright $\mathrm{MH}$, Matthews $\mathrm{B}$, Arnold MSJ, et al. The prevention of fish spoilage by high antioxidant Australian culinary plants: Shewanella putrefaciens growth inhibition. International Journal of Food Science and Technology. 2016;51(3):80113. DOI: $10.1111 /$ ijfs. 13026

19. Ilanko A, Cock IE. The interactive antimicrobial activity of contentional antibiotics and Petalostigma spp. Extracts against bacterial triggers of some autoimmune inflammatory diseases. Pharmacognosy Journal. 2019;11(1):292-309. DOI: 10.5530.pj.2019.11.45.

20. Mpala L, Chikowe G, Cock IE. No evidence of antiseptic properties and low toxicity of selected Aloe species. Journal of Pharmaceutical Negative Results 2010;1(1):10-6. DOI: 10.4103/0976-9234.68869

21. Maen A, Cock IE. Inhibitory activity of Australian cullinary herb extracts against the bacterial triggers of selected autoimmune diseases. Pharmacognosy Communications. 2015;5(2):130-9. DOI: 10.5530/pc.2015.2.4

22. Sirdaarta J, Matthews B, Cock IE. Inhibitory activity of Kakadu plum fruit extracts against microbial triggers of rheumatoid arthritis: Identification of stilbene and tannin components. Journal of Functional Foods. 2015;17:610-20.

23. Sirdaarda J, Matthews B, White A, et al. GC-MS and LC-MS analysis of Kakadu plum fruit extracts displaying inhibitory activity against microbial triggers of multiple sclerosis. Pharmacognosy Communications. 2015;5(2):100-15. DOI: 10.5530/pc.2015.2.2

24. Kalt FR, Cock IE. Gas chromatography-mass spectroscopy analysis of bioactive Petalostigma extracts: Toxicity, antibacterial and antiviral activities. Pharmacog Mag. 2014;10(Suppl 1):S37-49. DOI: 10.4103/0973-1296.127338

25. Cock IE. Antimicrobial activity of Callistemon citrinus and Callistemon salignus methanolic extracts. Pharmacognosy Communications. 2012;2(3):50-7. DOI: 10.5530/pc.2012.3.11

26. Cock IE. Antimicrobial activity of Acacia aulacocarpa and Acacia complanta methanolic extracts. Pharmacognosy Communications. 2012;2(1):66-71. DOI: 10.5530/pc.2012.1.12

27. Cock IE, Winnett $V$, Sirdaarta J, et al. The potential of selected Australian medicinal plants with anti-Proteus activity for the treatment and prevention of rheumatoid arthritis. Pharmacognosy Magazine. 2015;11(42 Suppl 1):S190-208. DOI: 10.4103/0973-1296.157734

28. Ruebhart DR, Wikramasinghe WA, Cock IE. Protective efficacy of the antioxidants vitamin $\mathrm{E}$ and Trolox against Microcystis aeruginosa and microcystin-LR in Artemia franciscana nauplii. Journal of Toxicology and Environmental Health Part A. 2009;72(24):1567-75.

29. Cock IE, Ruebhart DR. Comparison of the brine shrimp nauplii bioassay and the ToxScreen-II test for the detection of toxicity associated with Aloe vera (Aloe barbadensis Miller) leaf extract. Pharmacognosy Research. 2009;1(2):98-101.

30. Aiyegoro OA, Okoh Al. Use of bioactive plant products in combination with 
standard antibiotics: Implications in antimicrobial chemotherapy. Journal of Medicinal Plants Research. 2009;3(13):1147-52.

31. Cock IE. Antibacterial activity of selected Australian plant species. The Internet Journal of Microbiology. 2008;6:2.

32. Kalt FR, Cock IE. The medicinal potential of Australian native plants from Toohey Forest, Australia. South Pacific Journal of Natural Sciences 2011;28(1):41-7.

33. Paz EA, Cerdeiras MP, Fernandez J, et al. Screening of Uruguayan medicinal plants for antimicrobial activity. Journal of Ethnopharmacology. 1995;45(1):6770.

34. Cock IE, Vuuren SFV. Anti-Proteus activity of some South African medicinal plants: Their potential for the treatment and prevention of rheumatoid arthritis. Inflammopharmacology. 2014;22(1):23-36. DOI 10.1007/s10787-013-0179-3.

35. Cock IE, Vuuren SFV. The potential of selected some South African plants with anti-Klebsiella activity for the treatment and prevention of ankylosing spondylitis. Inflammopharmacology. 2014;23(1):21-35. DOI: 10.1007/s10787-014-0222-z

36. Palombo EA, Semple SJ. Antibacterial activity of traditional Australian medicinal plants. Journal of Ethnopharmacology. 2001;77(2-3):151-7.

37. Cock IE. Antimicrobial activity of Eucalyptus major and Eucalyptus baileyana methanolic extracts. Internet Journal of Microbiology. 2009;6(1):31.

38. Chikowe G, Mpala L, Cock IE. Antibacterial activity of selected Australian Syzygium species. Pharmacognosy Communications. 2013;3(4):77-83. DOI: 10.5530/pc.2013.4.11

39. Tortora GJ, Funke BR, Case CL. Microbiology: An Introduction, Benjamin Cummings, San Francisco. 2001.

40. Vesoul J, Cock IE. The potential of Bunya nut as an antibacterial food agent Pharmacognosy Communications. 2012;2(1):74-82. DOI: 10.5530/pc.2012.1.13
41. Vesoul J, Cock IE. An examination of the medicinal potential of Pittosporum phylloraeoides: Toxicity, antibacterial and antifungal activities. Pharmacognosy Communications. 2011:1(2):8-17. DOI: 10.5530/pc.2012.1.13

42. Kukkonen L, Cock IE. An examination of the medicinal potential of Scaevola spinescens: Toxicity, antibacterial and antiviral activities. Pharmacognosy Research. 2011;3(2):85-94. DOI: 10.4103/0974-8490.81955

43. Cock IE. The phytochemistry and chemotherapeutic potential of Tasmannia lanceolata (Tasmanian pepper): A review. Pharmacognosy Communications. 2013;3(4):13-25. DOI: 10.5530/pc.2013.4.3

44. Cai L, Wu CD. Compounds from Syzygium aromaticum possessing growth inhibitory activity against oral pathogens. Journal of Natural Products. 1996;59(10):987-90.

45. Waage SK, Hedin PA. Quercetin 3-O-galactosyl-(1, 4, 6)-glucoside, a compound from narrow leaf vetch with antibacterial activity. Phytochemistry. $1985 ; 24(2): 243-5$

46. Buzzini $P$, Arapitsas $P$, Goretti $M$, et al. Antimicrobial activity of hydrolysable tannins. Mini-Reviews in Medicinal Chemistry. 2008;8:1179-87.

47. Wolinsky LE, Sote EO. Isolation of natural plaque-inhibiting substances from 'Nigerian chewing sticks'. Caries Research. 1984;18(3):216-25.

48. Hogg SD, Embery G. Blood-group-reactive glycoprotein from human saliva interacts with lipoteichoic acid on the surface of Streptococcus sanguis cells. Archives in Oral Biology. 1982;27(3):261-8.

49. Wu-Yuan CD, Chen CY, Wu RT. Gallotannins inhibit growth, water-soluble glucan synthesis and aggregation of Streptococci mutans. Journal of Dental Research. $1988 ; 67(1): 51-5$

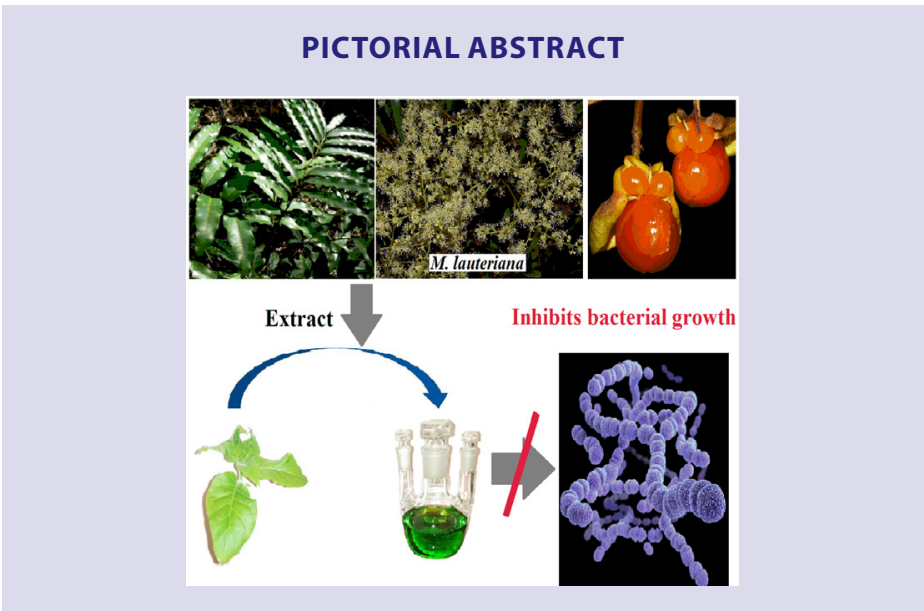

\section{SUMMARY}

- Methanolic and aqueous M. lauteriana leaf extracts were screened for the ability to block the growth of a panel of bacteria.

- The growth inhibition of both gram-positive and gram-negative bacteria was tested.

- The antibacterial activity was quantified by determining the MIC values of each extract.

- Growth time course studies were undertaken against the gram-positive bacterial species

- Toxicity of the M. lauteriana leaf extracts was determined using the Artemia nauplii toxicity bioassay.

\section{ABOUT AUTHORS}

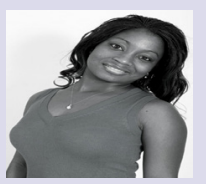

Ms Getmore Chikowe completed BSc at Griffith University in life sciences. Following graduation, she undertook a research project in Dr lan Cock's laboratory in the School of Natural Sciences at Griffith University. The project examined the growth inhibitory properties of a variety of Australian native plants against an extensive panel of bacterial pathogens.

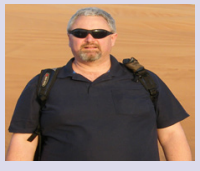

Dr lan Cock leads a research team in the Environmental Futures Research Institute and the School of Natural Sciences at Griffith University, Australia. His research involves bioactivity and phytochemical studies into a variety of plant species of both Australian and international origin, including Aloe vera, South Asian and South American tropical fruits, as well as Australia plants including Scaevola spinescens, Pittosporum phylliraeoides, Terminalia ferdinandiana (Kakadu plum), Australian Acacias, Syzygiums, Petalostigmas and Xanthorrhoea johnsonii (grass trees). This range of projects has resulted in nearly 200 publications in a variety of peer reviewed journals.

Ms Lindiwe Mpala completed at BSc Griffith University in life sciences. Following graduation, she undertook a research project in Dr lan Cock's laboratory in the School of Natural Sciences at Griffith University. The project examined the growth inhibitory properties of a variety of Australian native plants against an extensive panel of bacterial pathogens. 